\author{
ALDONA SKUDRZYK \\ (D) https://orcid.org/ 0000-0002-5503-5150 \\ Uniwersytet Śląski \\ Katowice
}

\title{
Dyglosja a proces socjalizacji
}

\begin{abstract}
Diglossia and the socialisation process
Abstract: The author discusses the concept of diglossia in the sociolinguistic aspect, but also in the cognitive one, assuming the significance of the opposition between the language of primary socialisation (unofficial and spoken) and the language of secondary socialisation (official and written) for the cognitive development of an individual functioning in a situation of diglossia. A broad interpretation of the concept is supported in the paper, with the author extending it to cover also the simultaneous presence of a minority language (as the language of primary socialisation) and the general language of the dominant culture (as the language of secondary socialisation) due to the clearly separate nature of their functioning.
\end{abstract}

Key words: diglossia, socialisation process, sociolinguistics, minority language

W opracowaniach poświęconych zagadnieniom dwujęzyczności (bilingwizmu) zwykle przywołuje się także pojęcie dyglosji (sytuacji dyglosyjnej), nieczęsto jednak staje się ono przedmiotem precyzyjniejszych omówień. Najczęściej eksponuje się nietypowość dyglosji w tym obszarze zjawisk, zwraca się uwagę na jej odrębność, eksponując specyfikę relacji między dwiema językowymi rzeczywistościami. Tak rozumiem propozycję badaczki dwujęzyczności Ewy Lipińskiej, wyróżniającej pewien jej typ, czyli bilingwizm społeczny, w którego obrębie sytuuje właśnie zjawisko dyglosji (Lipińska 2003, 128).

Tradycyjnie podkreśla się, że w dyglosyjnej relacji są odmiany tego samego systemu językowego, tego samego języka etnicznego. W takim bowiem rozumieniu (węższym) do socjolingwistyki wprowadził pojęcie dyglosji Charles Albert Ferguson w opublikowanym w 1959 roku artykule pt. Diglossia. Dla prowadzonych tu rozważań ważne jest przywołanie stanowiska Joshui Aarona 
Fishmana, który za istotne w dyglosji uznaje to, że jednym z owych językowych wariantów jest język wyuczony instytucjonalnie, a więc język nabywany w trakcie formalnej edukacji. Ten aspekt poszerza rozumienie dyglosji nie tylko o wymiar edukacyjny, ale także funkcjonalny, komunikacyjny. W tym nurcie sytuuje się Agata Nalborczyk, przyjmująca bliskie mi stanowisko: „Parę dyglosyjna moga zatem utworzyć jakiekolwiek warianty, jeśli tylko sposób ich funkcjonowania jest w danej społeczności komplementarny, a jeden z nich musi być nabywany w czasie oficjalnej edukacji”" (Nalborczyk 2003, 57). Takie, a więc szersze rozumienie zjawiska, chcę dopełnić pewnymi uwagami, eksponując wagę zjawiska w kontekście socjalizacji jednostki dorastającej w społeczności dyglosyjnej.

Instytucjonalne nauczanie języka oznacza po pierwsze, inny prestiż tak nabywanego języka (wysoki lub przynajmniej wyższy prestiż społeczny), po drugie, w biografii socjolingwistycznej jednostki jego wtórna pozycję w językowym rozwoju tej jednostki. Chcę spojrzeć na dyglosję, wskazując z jednej strony na jej aspekt komunikacyjny, z drugiej zaś - i może przede wszystkim - poznawczy. Nie sposób w rozwoju jednostki przecenić doświadczenia pierwszej socjalizacji, w tym socjalizacji językowej. W tej perspektywie nie ma znaczenia, czy podwójne językowo-kulturowe funkcjonowanie człowieka ma charakter rzeczywiście dwujęzyczny (w sensie dwusystemowy), czy też wynika z obecności dwu różnych odmian tego samego systemu. Dla rozwoju człowieczeństwa jednostki następstwa sa podobne - jeden z tych języków jest językiem pierwszej socjalizacji, sposobem wprowadzenia jednostki biologicznej w świat kultury społeczności najbliższego otoczenia. W tym sensie - szerszym - odnoszę pojęcie dyglosji także do sytuacji osób, których język pierwszy (język bliskości) jest systemowo różny od tego, który jednostkę wprowadza w świat instytucjonalny, oficjalny, pozarodzinny.

Proces socjalizacji odbywa się na kilku poziomach: najogólniejszy to pewne minimum kulturowe, które jest wymagane od wszystkich ludzi (porozumiewanie się, podstawowe zasady moralne); kolejny, niższy oznacza wejście do konkretnej kultury (np. opanowanie języka polskiego, polskich norm, obyczajów, wartości, symboli, narodowych tradycji), wreszcie najniższy poziom polega na opanowaniu konkretnych ról społecznych funkcjonujących w danej zbiorowości (Sztompka 2002, 393).

Przewodnikiem po tym poznawanym świecie staje się oczywiście język. Mówimy zatem o socjalizacji językowej, czyli o poznawaniu języka najbliższego otoczenia społecznego, języka pierwszego, którym potrafimy opisać świat, który niesie doświadczenie społeczne poprzednich pokoleń, a jego 
znaczeniowa strona - utrwalone sposoby kategoryzowania i wartościowania rzeczywistości. Tradycyjnie wyróżnia się socjalizację pierwotną, zachodząca od momentu narodzin jednostki, oraz socjalizację wtórną, która rozpoczyna się wraz z poszerzaniem kręgu jej kontaktów społecznych i komunikacyjnych. Ta pierwsza ,jest etapem najbardziej intensywnej edukacji kulturowej, który przypada na okres niemowlęctwa i wczesnego dzieciństwa" (Giddens 2004, 51). Rzeczywistość poznawana przez jednostkę podczas socjalizacji pierwotnej przyjmowana jest bez świadomości istnienia alternatyw, stanowi jej cały i jedyny świat. Jednostka poznaje język i nabywa wiedzę, ale przede wszystkim otrzymuje podstawowy drogowskaz aksjologiczny, czyli siatkę wartości, która w pierwszym okresie życia kształtuje jej osobowość, styl życia, wzory społecznego funkcjonowania, wreszcie określoną tożsamość kulturową oraz postawę wobec tej tożsamości. „Każda jednostka, rodząc się, wchodzi do obiektywnej struktury społecznej, w której napotyka innych, decydujących o jej socjalizacji. Ci znaczący inni są jej narzuceni, a ich definicje sytuacji sa przedstawiane jako obiektywna rzeczywistość" (Berger, Luckmann 1983, 204-205). Poprzez obcowanie ze „znaczacymi innymi” jednostka dowiaduje się, w co powinna wierzyć, jak realizować się w swej roli płciowej, jaki ma mieć stosunek do obcych, w jakie relacje wchodzić z rówieśnikami itd. Wszystko to, co poznaje podczas socjalizacji pierwotnej, jawi jej się jako normalność 1 .

Nabywanie języka - by zwrócić uwagę tylko na jego aspekt społeczno-poznawczy, najefektywniej odbywa się w trakcie rozmaitych interakcji z dorosłymi. Opanowanie reguł porozumiewania się oraz reguł języka jest jednym z istotnych składników socjalizacji językowej, a w jej przestrzeni zależy od jakości prowadzonych rozmów, właśnie od jakości, bo nie chodzi jedynie o wypowiadanie/znajomość słów danego języka, ale o rzeczywiste dialogi, pozwalające naprzemiennie realizować role nadawczo-odbiorcze; realizować wielorakie akty mowy, z ich wielorakimi intencjami; doświadczać komunikacyjnej codzienności, wchodzić w naturalne interakcje - słowem zależy od jakości ich bycia w języku.

Określając kulturę jako niszę rozwojową niezbędną do normalnego rozwoju poznawczego i społecznego, Michael Tomasello wyróżnia

1 Oprócz „znaczących innych” na rozwój jednostki w pierwszej fazie socjalizacji mają także wpływ tzw. instytucje pośredniego wychowania: pismo, druk, ilustracje, telefon, kino i radio, telewizja oraz tzw. nowe media, czyli przede wszystkim internet. Umożliwiają one kontakt z cudzym doświadczeniem, są - niedającym się dziś pominąć - jednym z ważniejszych czynników socjalizacyjnych. 
dwa sposoby, jakimi ludzkie środowisko kulturowe reguluje kontekst rozwoju poznawczego dzieci. Określam je jako „zwyczajowość” poznawczą i jako źródło aktywnego instruktażu dawanego dzieciom przez dorosłych. (...) Uczestnictwo dziecka w typowych praktykach ludzi, wśród których rośnie (...) determinuje rodzaje interakcji społecznych, w jakie będzie ono wchodzić, rodzaje dostępnych dla niego przedmiotów fizycznych, rodzaje doświadczeń i możliwości uczenia się, jakie napotka, oraz rodzaje wniosków, jakie będzie wyciagało na temat sposobu życia otaczających je ludzi (Tomasello 2002, 109).

Takie praktyki interakcyjne stwarzają - mówiąc językiem Tomasello, „sceny/konteksty wspólnej uwagi”, pozwalające dziecku postrzegać intencjonalność komunikatu, możliwość odwracania ról komunikacyjnych, co warunkuje zdolność aktywnego używania symboli językowych. Ze względu na doniosłość i trwałość pierwszych doświadczeń socjalizacyjnych używanie języka pierwszej socjalizacji (odmiany języka bądź innego języka mniejszościowego), jego możliwości i zakres konceptualizacji świata stają się nie tylko pierwszym doświadczeniem komunikacyjnym, stają się wzorcem funkcjonowania w mowie ogólnej, osiągając rangę wzorca kompetencji komunikacyjnej w ogóle.

Cały ten proces ma charakter kulturowy, a nie uniwersalny - podkreślmy to, mając na uwadze siłę nawyków wówczas wykształconych.

W perspektywie dyglosyjnej istotne jest przejście na poziom edukacji instytucjonalnej - poznawanie nowego języka: może to być poznawanie ogólnej odmiany języka etnicznego wobec znanej z pierwszego etapu życia odmiany regionalnej gwarowej, ale także poznawanie nowego języka wobec znanego dotąd wzorca języka mniejszości etnicznej. Jak widać, nie tylko języka, ale nade wszystko środowiskowych, kulturowych reguł jego używania.

Ten nowy sposób komunikowania się (nowy język) przede wszystkim otwiera na nowe socjolingwistycznie funkcje, ma wyraźnie zakreślona przestrzeń komunikacyjną: 1) występuje jako wariant komunikacji ustnej w sytuacjach oficjalnych; a także 2) służy jako narzędzie porozumiewania się w formie pisanej. Pierwsze doświadczenie komunikacyjne na etapie socjalizacji pierwotnej to poznawanie języka mówionego, nabywanie kolejno sprawności systemowej, sytuacyjnej, poszerzanie i doskonalenie sprawności pragmatycznej, odkrywanie uwarunkowań sprawności społecznej, poznawanie funkcji języka i funkcji tekstów, wypowiedzi w wersji ustnej.

Kolejny etap rozwoju społecznego i językowego - socjalizacja wtórna - to okres wchodzenia w relacje oficjalne i zapośredniczone przez instytucje oraz 
pismo. W odniesieniu do socjalizacji językowej mówimy o procesie rozwijania nabytego już języka, powstawania oraz rozwijania umiejętności operowania „językami” obsługującymi nowe wyspecjalizowane sfery życia. Rozwój ten jest ściśle związany z mobilnością społeczną. Niezależnie jednak od niej - zasadniczo dostępny każdemu użytkownikowi języka - jest przełomowy w rozwoju naszej biografii socjolingwistycznej etap poznawania języka w jego odmianie pisanej (innej substancjalnej wersji poznanego już systemu językowego).

Zarówno w rozwoju indywidualnym jednostki, jak i w dziejach ludzkości wynalazek pisma widzieć należy jako niezwykle doniosły w swych następstwach kulturowo-komunikacyjnych.

W nauce powszechne jest przekonanie, że pismo stworzyło nowocześnie myślącego człowieka, rozwija się bogaty w osiagnięcia nurt badań nad piśmiennością (literacy). Punktem wyjścia tych badań jest przyjęcie tezy, że opozycja mówienia i pisania nie sprowadza się tylko do różnicy substancji (dźwięk, głoska, zachowania niewerbalne - litera, reguły ortograficzne, reguły gatunkowe, interpunkcja). Pierwotnej, podstawowej postaci języka uczymy się w pierwszym etapie socjalizacji. Tworzywem tej odmiany jest substancja dźwiękowa. Stąd wynika z jednej strony ulotność, nietrwałość komunikatu ustnego, z drugiej - ważność takich elementów, jak tempo mówienia, głośność, barwa głosu, intonacja, akcentowanie wyrazów, przedłużanie niektórych głosek, dłuższe lub krótsze pauzy.

Najbardziej charakterystyczna, typowa dla odmiany mówionej jest komunikacja bezpośrednia - „twarzą w twarz” (face to face), podstawową formą języka mówionego jest więc forma rozmowy. Zakłada ona wzajemny udział rozmówców w budowaniu tekstu ustnego. Każdy z uczestników rozmowy jest nadawcą i odbiorca zarazem, tekst mówiony jest wynikiem ich współdziałania, jest przez nich współtworzony. Bezpośredni kontakt mówiących ma wpływ na kształt językowy komunikatu. Nie wszystkie informacje wypowiadane są wprost i w sposób zgodny z normą obowiązującą w piśmie. Kolejna cecha mówienia to sytuacyjność rozumiana jako swego rodzaju „niesamodzielność” warstwy językowej, która w sposób naturalny związana jest z otoczeniem mówienia, przedmiotami i osobami, będącymi w zasięgu wzroku itp. Stąd wiele możemy powiedzieć, np. wskazując, a nazwę konkretną zastępując zaimkiem. Wiele informacji przekazać można, używając gestów, mimiki, odpowiednio kształtując przestrzeń mówienia, odległość między rozmówcami. Ruchy ciała mogą wzmacniać lub osłabiać oddziaływanie słów, mogą je modyfikować lub im zaprzeczać. Ta cecha mówienia 
określana jest jako wielokodowość. Kodowi językowemu (werbalnemu, czyli systemowi języka) towarzyszy kod niewerbalny - na kod ten składają się trzy typy znaków pozasłownych (pozajęzykowych). Są to znaki: prozodyczne tempo mówienia, intonacja, wysokość i barwa głosu, rytm, towarzyszące dźwiękom mowy; kinezyczne - czyli gesty, zachowania ruchowe, mimiczne towarzyszące mówieniu lub je zastępujące; proksemiczne, czyli dające się komunikacyjnie interpretować wykorzystanie odległości między rozmówcami.

Wszystkie te cechy komunikacji mówionej, podkreślmy to ponownie, mają charakter kulturowy - przenikamy nimi niejako kształtowani przez pierwszy etap socjalizacji. Mówienie współtworza ponadto: kod zapachowy (olfaktoryczny), dotykowy, wzrokowy, prezencyjny (zewnętrzny wygląd człowieka), temporalny.

Bycie w każdej z tych kultur - w kulturze mówienia i w kulturze pisma warunkuje inny styl poznawczy, inny sposób myślenia. W życiu jednostki oznacza proces przechodzenia od pierwotnej postaci myślenia konkretno-wyobrażeniowego do myślenia logicznego (abstrakcyjnego). Dotychc zasowe nawyki komunikacyjne, jak każde działanie dziecka we wczesnym etapie rozwoju, były silnie związane z sytuacją². Jak pisze Wygotski:

U dziecka w okresie wczesnego dzieciństwa istnieje tak ścisłe powiązanie między słowem i rzecza, znaczeniem i tym, co jest widziane, że rozdzielenie pola wizualnego od pola sensu staje się niemożliwe. (...) Słowo pierwotnie oznacza znane miejsce w sytuacji. W zabawie w wieku przedszkolnym obserwujemy po raz pierwszy rozchodzenie się pola wizualnego i pola sensu (Wygotski 2002, 152-153).

To w trakcie rozwoju myślenia i mowy znaczenie „wyzwala się od rzeczy”, co jest koniecznym etapem umożliwiającym przejście do myślenia abstrakcyjnego.

${ }^{2}$ Eksperymenty, które opisuje Wygotski, pokazuja, że ta zależność od sytuacji - całkowita we wczesnym wieku dziecięcym (dziecko dwuletnie nie potrafi powiedzieć zdania „Tania idzie”, jeśli Tania w tym właśnie momencie siedzi na krześle przed nim), funkcjonuje nadal w życiu dorosłych, choć oczywiście w innym wymiarze. „W eksperymentach Lewina (...): badanego zaprasza się do laboratorium, po czym eksperymentator wychodzi na kilka minut pod pretekstem poczynienia koniecznych przygotowań, zostawiając badanego w nowych dla niego warunkach. Eksperymentator czeka na zewnątrz 10-15 minut. W takiej sytuacji badany najczęściej zaczyna rozglądać się po pokoju. Gdy dostrzeże zegarek - spogląda, która godzina, jeśli leży koperta - sprawdza, czy coś w niej jest. W taki sposób każde działanie człowieka, które określone jest przez to, co on widzi, przypomina zachowanie dziecka w okresie wczesnego dzieciństwa" (Wygotski 2002, 93). 
Doniosłość odkrycia pisma polega nie tylko na stworzeniu możliwości przechowywania i utrwalania mowy, lecz przede wszystkim na dekontekstualizacji, czyli uniezależnieniu mowy od sytuacji jej powstania. Zarówno jako nadawcy, jak i odbiorcy możemy dzięki temu wyjęciu z kontekstu i unieruchomieniu tekstu skupić się całkowicie na jego opracowaniu (jako nadawcy) lub jego interpretacji, analizie (jako odbiorcy). Takie podejście do tekstu rozwinęło nasze (ogólnie ludzkie, ale i nasze indywidualne) umiejętności poznawcze: racjonalność, sceptycyzm, logikę, wiązanie przyczyn z ich przewidywanymi skutkami, czyli, inaczej mówiąc, rozwinęło myślenie logiczne. Rozwojowi podlegać mogły nadto systemy klasyfikacji, myślenie w kategoriach relacji, kategoryzowania. Wynikają z tego ważne następstwa - opanowywanie prestiżowego języka wiąże się bowiem z nową jakością kulturową. Istotną cechą definicyjną dyglosji jest nierówność statusu obu używanych językowych odmian, dla społeczności mniejszościowych to niezwykle istotne, bywają wszak takie, które odmiany oficjalnej albo pisanej nie wykształciły, albo nie mają warunków, okoliczności, potrzeby, by jej używać (por. sytuację Romów i ich języka). Przyswajanie języka polskiego przez dzieci pochodzące $z$ mniejszości etnicznych ma cechy nabywania języka o wysokim prestiżu w sytuacji dyglosyjnej. Styl wysoki, język prestiżu staje się niejako podwójnie obcy. Pierwszy język - czy to odmiana regionalna (także potoczna odmiana polszczyzny), czy to mówiony język mniejszości odnosił się tylko do świata codzienności, zatem gdy uczeń zaczyna podlegać instytucjonalnemu uczeniu się, zamiast poznawać nowe rzeczy, musi nauczyć się na nowo nazywać pojęcia i przedmioty, a proces ten ma cechy uczenia się języka obcego. Za Idą Kurcz zwróćmy uwagę na istotne odróżnienie przyswajania języka od jego uczenia się. Obie postawy poznawcze odniesiemy łatwo do omawianego tu zagadnienia: „Przyswajanie dokonuje się w sposób naturalny, automatycznie i samorzutnie u małego dziecka, wystarczy po prostu swobodny dostęp do wypowiedzi językowych w jego otoczeniu. Uczenie się wymaga wysiłku, motywacji, sprzyjają mu określone zdolności” (Kurcz 2000, 182).

Zaakcentujmy wspomniany problem motywacji i wysiłku - wyraźnie da się wskazać na moc języka, o której, z jej wielowymiarowymi uwarunkowaniami, pisze Władysław Miodunka - jako przyczynę łatwiejszego bądź trudniejszego przyswajania języka kultury społecznie dominującej.

W interesującym studium Jagody Cieszyńskiej (2006) na temat dwujęzyczności i dwukulturowości autorka przyjmuje, że osoba dwujęzyczna różni się w przetwarzaniu informacji językowych od jednojęzycznej, a przytaczając wyniki badań Krystyny Wróblewskiej-Pawlak (2004), Cieszyńska precyzuje, że 
dwujęzyczni w porównaniu z jednojęzycznymi, generalnie potrzebuja więcej czasu na odpowiedź w zadaniach związanych z dekodowaniem, co jest interpretowane jako konieczność analizy większej liczby możliwych alternatyw, jakie muszą rozpatrzyć, dysponując podwójnym repertuarem językowym (Cieszyńska 2006, 42).

Łatwo zatem uznać, że równoczesne funkcjonowanie w języku domowym (odmianie regionalnej lub języku mniejszościowym) i języku ogólnym stać się może przyczyną utrudnień edukacyjnych, bowiem: „o ile sytuacja bilingwizmu stwarza możliwości rozwoju poznawczego, o tyle sytuacja dyglosji może być czynnikiem hamującym nabywanie wiedzy, utrudniając edukację szkolną dzieci" (Cieszyńska 2006, 55). Te utrudnienia dla rozwoju poszczególnych jednostek funkcjonujących w relacjach dyglosyjnych moga mieć istotne następstwa nie tylko społeczne, ale i psychologiczne, stając się przyczyna poczucia wykluczenia ze wspólnoty. Wydaje się, że problem ten nie tylko dla glottodydaktyki powinien mieć znaczenie, gdyż instytucjonalna edukacja dotycząca języka prestiżu ma wymiar znacznie szerszy niż tylko przekazywanie zasad i reguł nowego języka.

Dyglosja widziana przez pryzmat uwarunkowań socjologicznych, psychologicznych, wreszcie poznawczych, wydaje się w obecnej rzeczywistości zjawiskiem coraz szerzej obecnym we współczesnym świecie. Z jednej strony kulturowo, ekonomicznie globalizującym się, z drugiej szukającym poczucia zakorzenienia, które jest podstawowa potrzebą każdego człowieka. Bez zakorzenienia się w „swojszczyźnie” człowiek jest społecznie martwy, bo , jest znikąd”. Świadomość małej ojczyzny (także lub przede wszystkim językowej) staje się wartością samą w sobie, jest punktem odniesienia dla innych wartości. Wpływa na postrzeganie, ocenę i rozumienie zjawisk i sytuacji przez pryzmat własnej rzeczywistości. Powrót do korzeni własnej kultury, trwanie w swym pierwszym języku bliskości chroni przed zagubieniem w kulturze masowej i anonimowej społeczności, jest odpowiedzią na cywilizację globalna, na uniformizację życia społecznego. Pozwala być może zachować swoją indywidualność, tożsamość, odrębność własnej kultury i zdolność do życia we wspólnocie.

Literatura

Berger P., Luckmann T., 1983, Społecそne tworzenie rzeczywistości, Warszawa. Cieszyńska J., 2006, Dwujezyczৃność, dwukulturowość - pržeklenstwo czy bogactwo? O poszukiwaniu tożsamości Polaków w Austrii, Kraków. 
Ferguson Ch.A., 1959, Diglossia, "Word", vol. 15, issue 2.

Fishman J.A., 1991, Bilingual education, Amsterdam-Philadelphia.

Giddens A., 2004, Socjologia, przeł. Szulżycka A., Warszawa.

Kurcz I., 2000, Psychologia jezylka i komunikacji, Warszawa.

Lipińska E., 2003, Jezyk ojczysty, jezyk obcy, jezylk drugi. Wstęp do badań dwujezyczności, Kraków.

Miodunka W., 1990, Moc jezyka i jej znaczenie w kontaktach jezykowych $i$ kulturowych, w: Miodunka W., red., Jezyke polski w śmiecie. Zbiór studiów, Warszawa-Kraków.

Nalborczyk A.S., 2003, Zachowania jezykowe imigrantów arabskich w Austrii, Warszawa.

Sztompka P., 2002, Socjologia, Kraków.

Skudrzyk A., Warchala J., 2012, Literacy of The Young Generation in a Diglossic Environment, Katowice.

Tomasello M., 2002, Kulturowe źródła ludzłeiego poznawania, przeł. Rączaszek J., Warszawa.

Wróblewska-Pawlak K., 2004, Jezyk - Tożsamość - Imigracja. O strategiach adaptacyjnych Polaków zamieszkalych we Francii w latach osiemdriesiatych XX wieku, Warszawa.

Wygotski L.S., 2002, Wybrane prace psychologiczne II: Drieciństwo i dorastanie, przeł. Brzezińska A. i in., Poznań. 